\title{
The Perspectives in the Management for Warfarin Resistance and Toxicity Associated with Vitamin K Epoxide Reductase Dysfunction
}

\author{
Ahmed Abdul-Sabour Bader* \\ Department of Clinical Pharmacology, Egypt
}

Submission: July 14, 2017; Published: August 16, 2017

*Corresponding author: Ahmed Abdul-Sabour Bader, Department of Clinical Pharmacology, Faculty of Medicine, Menoufiya University, Egypt, Email: ahmedpharma7@gmail.com

\section{Introduction}

Anticoagulant therapy is being increasingly used the treatment and prevention of thromboembolic events, and warfarin remains the most frequently used agent for longterm anticoagulation in all patient groups. Warfarin, one of oral anticoagulant drugs that exerting its anticoagulant effect by inhibiting the enzyme vitamin $\mathrm{K}$ epoxide reductase (VKORC1), thereby preventing vitamin $\mathrm{K}$ recycling and vitamin K-dependent carboxylation of the coagulation factors II, VII, IX, and $\mathrm{X}$; where the carboxylation is very critical for biosynthesis of these blood clotting factors leading to a marked decrease in blood coagulation process [1]. Anticoagulation response to a fixed dose of warfarin is notoriously difficult to predict because of interindividual variability in dose requirement. This, together with the drug's narrow therapeutic window, necessitates maintenance of anticoagulation status within a tight therapeutic range facilitated by frequent international normalized ratio (INR) monitoring to ensure the efficacy and safety of therapy.

Warfarin resistance may develop as a result of noncompliance, exogenous consumption of vitamin $\mathrm{K}$, and concurrent ingestion of other agents known to decrease warfarin's effects [2]. Unfortunately, an increasing number of genetic variations of enzyme vitamin $\mathrm{K}$ epoxide reductase affecting warfarin pharmacodynamics and/or pharmacokinetics were found to have a major impact on the warfarin dose in adults that had been found to produce detrimental harmful effects on body due to either over coagulation or under coagulation (resistance) to its therapeutic action. These genetic variations are found in single nucleotide polymorphisms (SNPs) in VKORC1 that leading to loss of VKORC1 sensitivity to warfarin; making it difficult or impossible to adequately lower vitamin K levels [3-6].

Some studies reported that there were a genetic variations found in single nucleotide polymorphisms (SNPs) located in the
VKORC1 gene have the largest effect on the response to warfarin. More specifically, it was reported that patients carrying some genetic variations located in the functional promoter of VKORC1 gene require substantially lower doses than do wildtype patients with genetic variations located in other parts of VKORC1 gene making them need large doses of warfarin [4-8].

\section{Future Perspectives Management}

Lycopene is a carotenoid-a family of pigments that give fruits and vegetables their brilliant red, orange, and yellow coloring in fruits such as tomatoes, apricots, papayas, guava, watermelon and pink grapefruit. It is reported as a powerful antioxidant that sops up unstable molecules (free radicals) that induce DNA damage, kill cells, attack proteins, in the body, and prevent blood vessel diseases, and furthermore, the antioxidant activity of lycopene is reported as higher than other carotenoids, including beta-carotene. Some evidence suggests that lycopene quells inflammation, limits cholesterol production, boost immunity and inhibits blood clotting. All of these may help reduce ischemic strokes, which are caused by clot-caused blockages in blood flow to the brain [9].

The effect of lycopene on protecting blood cell, promoting fibrinolytic activity and reducing aortic lesions in hyperlipidemic rats might be the result of reducing blood lipids and improving antioxidation [10]. In humans, lycopene has demonstrated hypotensive activity [11], and several human trials indicated a cholesterol-lowering effect [12]. One of the mechanisms by which lycopene prevent platelet aggregation is by activating cyclic-GMP, a signaling molecule involved in vessel dilation. In 2012, Karppi et al. in a prospective study showed that high serum concentrations of lycopene, as a marker of intake of tomatoes and tomato-based products, decreased the risk of any stroke and ischemic stroke in men. In 2013, Jacques et al. [13] reported 
evidence for an inverse association between lycopene and CVD risk. New evidence suggests that it is circulating lycopene and not the dietary lycopene which is associated with a significant decrease in stroke risk [14].

Resveratrol (3, 5, 4'-trihydroxystilbene), a naturally occurring plant polyphenol found in grapes and red wine, is a potent antioxidant and anti-inflammatory agent that has been shown to protect diverse tissue types including brain, heart, and kidney tissue in experimental models. In 2006 Olas and Wachowicz, and in 2007, Shen et al. reported that resveratrol possessed significant protective effects in thromboembolicrelated disorders by inhibiting platelet aggregation $[15,16]$. The mechanisms of resveratrol involved inhibition of collageninduced platelet activation accompanied by intracellular calcium mobilization, thromboxane A2 formation, phosphoinositide breakdown, and protein kinase $\mathrm{C}$ activation. In addition, it was reported to markedly increase levels of nitric oxide/cyclic guanosine monophosphate (GMP), and cyclic GMP-induced vasodilator-stimulated phosphoprotein phosphorylation [16]. Plasma resveratrol from consumption of red or white wine increases the release of nitric oxide from platelets in healthy volunteers, inhibiting their activation [17].

In 2009, Della-Morte et al. [18] reported that rats pretreated with resveratrol prior to cardiac arrest reduced hypoxic neuronal death through modulation of adenosine triphosphate synthesis. In 2011, Malinowska and Olas, suggested that resveratrol could suppress the detrimental effects of homocysteine on platelet aggregation and free radical generation [19]. Additionally, in 2014, Nabavi et al. [20] reported that the beneficial effects of resveratrol against most cardiovascular and cerebrovascular diseases; is largely attributed to its antioxidant properties and concluded that resveratrol possesses cardioprotective actions through stimulation of nitric oxide production as well as antioxidative and anti-inflammatory effects.

\section{Conclusion}

The underlying potential cardio-protective activities of both lycopene and resveratrol in several cardiovascular disorders; can be used to ameliorate the clotting disorders resulting from vitamin $\mathrm{K}$ epoxide reductase deficiency and may help people with warfarin resistance or dysfunctional warfarin activity.

\section{Reference}

1. Stafford DW (2005) The vitamin K cycle. J Thromb Haemost 3(8): 1873-1878.

2. Hulse ML (1996) Warfarin resistance: diagnosis and therapeutic alternatives. Pharmacotherapy 16(6): 1009-1017.

3. Rieder MJ, Reiner AP, Gage BF, Nickerson DA, Eby CS, et al. (2005) Effect of VKORC1 haplotypes on transcriptional regulation and warfarin dose. N Engl J Med 352(22): 2285-2293.

4. Andrea GD, Ambrosio RLD, Perna PD, Chetta M, Santacroce R, et al. (2005) A polymorphism in the VKORC1 gene is associated with an interindividual variability in the dose-anticoagulant effect of warfarin. Blood 105(2): 645-649.

5. Schwarz UI, Ritchie MD, Bradford Y, Li C, Dudek SM, et al. (2008) Genetic determinants of response to warfarin during initial anticoagulation. $\mathrm{N}$ Engl J Med 358(10): 999-1008.

6. Harrington DJ, Gorska R, Wheeler R, Davidson S, Murden S, et al. (2008) Pharmacodynamic resistance to warfarin is associated with nucleotide substitutions in VKORC1. J Thromb Haemost 6(10): 1663-1670.

7. Gage BF, Eby C, Johnson JA, Deych E, Rieder MJ, et al. (2008) Use of pharmacogenetic and clinical factors to predict thetherapeutic dose of warfarin. Clin Pharmacol Ther 84(3): 326-331.

8. Bodin L, Verstuyft C, Tregouet DA, Robert A, Dubert L, et al. (2005) Cytochrome P450 2C9 (CYP2C9) and vitamin K epoxide reductase (VKORC1) genotypes as determinants of acenocoumarol sensitivity. Blood 106(1): 135-140.

9. Seppa N (2012) Tomato compound might prevent some strokes. Science News.

10. Xu X, Zhu M, Hu M (2011) Effects of lycopene on blood cells and fibrinolytic activity in hyperlipidemic rats. Wei Sheng Yan Jiu 40(5): 620-623.

11. Engelhard YN, Gazer B, Paran E (2006) Natural antioxidants from tomato extract reduce blood pressure in patients with grade-1 hypertension: a double-blind, placebo-controlled pilot study. Am Heart J 151(1): 100.

12. Ried K, Fakler P (2011) Protective effect of lycopene on serum cholesterol and blood pressure: Meta-analyses of intervention trials. Maturitas 68(4): 299-310.

13. Jacques PF, Lyass A, Massaro JM, Vasan RS, Agostino RBD (2013) Relationship of lycopene intake and consumption of tomato products to incident CVD. Br J Nutr 110(3): 545-651.

14. Li X, Xu J (2014) Dietary and circulating lycopene and stroke risk: a meta-analysis of prospective studies. Sci Rep 4: 5031.

15. Olas B, Wachowicz B (2005) Resveratrol, a phenolic antioxidant with effects on blood platelet functions. Platelets 16(5): 251-260.

16. Shen MY, Hsiao G, Liu CL, Fong TH, Lin KH, et al. (2007) Inhibitory mechanisms of resveratrol in platelet activation pivotal roles of p38 MAPK and NO/cyclic GMP. Br J Haemato 139(3): 475-485.

17. Gresele P, Pignatelli P, Guglielmini G, Carnevale R, Mezzasoma AM, et al. (2008) Resveratrol, at concentrations attainable with moderate wine consumption, stimulates human platelet nitric oxide production. J Nutr 138(9): 1602-1608.

18. Della MD, Dave KR, De Fazio RA, Bao YC, Raval AP, et al. (2009) Resveratrol pretreatment protects rat brain from cerebral ischemic damage via a sirtuin 1-uncoupling protein-2 pathway. Neuroscience 159(3): 993-1002.

19. Malinowska J, Olas B (2011) Response of blood platelets to resveratrol during a model of hyperhomocysteinemia. Platelets 22(4): 277-283.

20. Nabavi SF, Huige L, Daglia M, Nabavi SM (2014) Resveratrol and stroke: from chemistry to medicine. Curr Neurovasc Res 11(4): 390-397. 

CC Commons Attribution 4.0 Licens

DOI: 10.19080/OAJT.2017.01.555565
Your next submission with Juniper Publishers will reach you the below assets

- Quality Editorial service

- Swift Peer Review

- Reprints availability

- E-prints Service

- Manuscript Podcast for convenient understanding

- Global attainment for your research

- Manuscript accessibility in different formats

( Pdf, E-pub, Full Text, Audio)

- Unceasing customer service

Track the below URL for one-step submission https://juniperpublishers.com/online-submission.php 